Revista Brasil. Bot., V.25, n.1, p.103-115, mar. 2002

\title{
Ovule ontogeny of Tabebuia pulcherrima Sandwith (Bignoniaceae): megasporogenesis and integument development
}

\author{
NELSON S. BITTENCOURT JÚNIOR ${ }^{1,3}$ and JORGE E.A. MARIATH ${ }^{2}$
}

(received: January 24, 2001; accepted: January 16, 2002)

\begin{abstract}
Ovule ontogeny of Tabebuia pulcherrima Sandwith (Bignoniaceae): megasporogenesis and integument development). The ovule of Tabebuia pulcherrima is anatropous, unitegmic and tenuinucellate. The nucellus shows a trizonate structural organization. The integument is initiated by periclinal divisions in the dermal layer (zone I), around the base of the archesporium. Subsequently, cells derived from the subdermal layer (zone II) start to push the dermal cells, so that they shift toward the micropylar region. The archesporial cell differentiates directly into the megaspore mother cell, undergoes meiosis, and originates a linear tetrad of megaspores. The mature embryo sac mother cell is elongated, possess a conspicuous central nucleus, and a characteristic bipolar vacuome with fibrous-granulated content. The inner cell layers of the integument differentiate into an amyloplast-rich endothelium. Patterns of callose deposition in the tetrad and selection of the functional megaspore, as well as the taxonomic value of some characters are discussed.
\end{abstract}

RESUMO - (Ontogenia do óvulo de Tabebuia pulcherrima Sandwith (Bignoniaceae): megasporogênese e desenvolvimento do tegumento). Os óvulos de Tabebuia pulcherrima são anátropos, unitégmicos e tenuinucelados. Os nucelos apresentam estrutura trizonada. O tegumento é iniciado por divisões periclinais na camada dérmica (zona I), ao redor da base do arquespório. Em seguida, células derivadas da camada subdérmica (zona II) tomam parte na constituição do tegumento, empurrando as células de origem dérmica para a região micropilar. A célula arquespórica diferencia-se diretamente em megasporócito, sofre meiose e origina uma tétrade linear de megásporos. A célula-mãe do megásporo madura é alongada, com núcleo central e vacuoma bipolar apresentando conteúdo fibro-granular. As camadas celulares mais internas do tegumento diferenciam-se em endotélio rico em amiloplastos. Padrões de deposição de calose na tétrade e da seleção do megásporo funcional, bem como o valor taxonômico de alguns caracteres são discutidos.

Key words - Integument, megasporogenesis, ovule ontogeny, Tabebuia, Bignoniaceae

\section{Introduction}

The integument ontogeny, details of the megaspores and embryo sac mother cell differentiation have scarcely been studied in angiosperms. The great applicability of integument ontogenetic studies to the understanding of different types of integumentary systems, their mode of evolution and their implications for the taxonomy of different groups of angiosperms have been stressed in several publications (Bouman 1971, Bouman \& Calis 1977, Bouman \& Schier 1979, Bouman 1984). As far as we know, Galati \& Strittmatter (1999) is the only report on the ontogenetic origin of the tegument in a species of Bignoniaceae.

The inner epidermis of the inner integument in bitegmic ovules and that of the single integument in

1. Universidade Estadual de Campinas, Departamento de Botânica, Caixa Postal 6109, 13083-970 Campinas, SP, Brazil.

2. Universidade Federal do Rio Grande do Sul, Departamento de Botânica, Laboratório de Anatomia Vegetal, Av. Bento Gonçalves 9500, Prédio 43423, Sala 206, 91501-970 Porto Alegre, RS, Brazil. jorge.mariath@ufrgs.br

3. Corresponding author: nesbitte@unicamp.br unitegmic ovules, in several families of angiosperms, becomes differentiated as a specialized layer of radially elongated cells with dense cytoplasm and prominent, often polyploid, nuclei. This tissue, the endothelium, is quite common in families of unitegmic and tenuinucellate ovules (Kapil \& Tiwari 1978a). In several Bignoniaceae, including Tabebuia, a markedly differentiated endothelium has been observed (Govindu 1950, Ghatak 1956, Mehra \& Kulkarni 1985, Bittencourt Jr. 1992). Different functions have been attributed to the endothelium according to the taxon and to the ovule developmental stage (Kapil \& Tiwari 1978a, b). A broad overview of the functional and evolutionary significance of this intriguing tissue will not be possible without studies of a number of different specific cases.

According to Shivaramiah (1998), morphological and embryological investigations in the Bignoniaceae are far from complete with respect to its systematic position. Bignoniaceae is a family of approximately 800 species (Spangler \& Olmstead 1999), and few of these species have been studied in relation to ovule development (Duggar 1899, Mauritzon 1935, Swamy 1941, Govindu 1950, Ghatak 1956, Mehra \& Kulkarni 1985, Bittencourt Jr. 1992, Galati \& Strittmatter 1999). In these studies, 
104 N.S. Bittencourt Júnior \& J.E.A. Mariath: Megasporogenesis and integument development of Tabebuia pulcherrima

the attention given to details of meiocyte divisions, functional megaspore maturation, and associated events has been almost null. The present study is the first of two papers dealing with the ovule development of Tabebuia pulcherrima, a common tree of the coastal south Brazilian "restingas". The aims of this study were to investigate megasporogenesis, embryo sac mother cell maturation, formation of the integument and its endothelium, and to contribute with embryological data for the taxonomy of Bignoniaceae.

\section{Material and methods}

Plant collections were carried out from August to November of 1993 and 1994. Inflorescences with floral buds, in different stages of development, were collected from a native (ICN 106186) and three cultivated trees (ICN 106184, 106185 and 103826 - Department of Botany, Universidade Federal do Rio Grande do Sul) located in the metropolitan area of Porto Alegre, Brazil.

The flower buds were dissected to isolate gynoecia, which were fixed in glutaraldehyde $2 \%$ in sodium phosphate buffer 0.1 M, pH 6,8 (Gabriel 1982). Fixation was done at room temperature, immediately after each collection (Robards 1985). After fixation the material was stored in ethanol $70 \%$ at low temperature. After dehydration in ethyl series, the samples were embedded in hydroxyethylmethacrylate (Historesin Jung). The blocks were sectioned in a Leitz 1400 microtome, in sections 1 to $4 \mu \mathrm{m}$ thick. The sections were mounted on glass slides and submitted to histochemical tests, or stained with toluidine blue O (O'Brien \& McCully 1981), acid fucsin and toluidine blue O (O'Brien \& McCully 1981), or astra blue and basic fucsin (adapted for historesin sections, from Johansen (1940) and Gerlach (1977) methods).

Several histochemical tests were performed: the periodic acid Schiff reaction (PAS) for the detection of insoluble polysaccharides (except cellulose and callose), after treating the sections with dinitrophenyl-hydrazine (O'Brien \& McCully 1981); IKI test for amyloplasts (Sass 1940), together with examination using optical microscopy with polarized light; Sudan IV (Johansen 1940), or Sudan black B (O'Brien \& McCully 1981) for detection of apolar substances (insoluble lipids); aniline blue as a fluorochromatic method for callose (Eschrich \& Currier 1964); ruthenium red for acid polysaccharides, including pectic acids (Southworth 1973).

The results of the preparations were documented with drawings using a camera lucida and photomicrographic records. The drawings and photomicrographies were made with a Leitz Dialux 20EB microscope. Pictures were taken with Ektachrome 64 ASA and T-MAX 100 ASA Kodak films.

Ovules were also examined by scanning electron microscope (SEM). Carpel walls were removed to expose the ovules. The samples were dehydrated, submitted to critical point drying (Gersterberger \& Leins 1978) in a Balzers CPD
030 equipment, and mounted on aluminum stubs. The material was coated with gold in a Balzers SCD 050 sputtering system, and examined with SEM Jeol Series 300, at $25-30 \mathrm{keV}$.

\section{Results}

At each face of the septum in the bilocular ovary of $T$. pulcherrima, the placentae are disposed as two longitudinal fleshy crests, where the ovules are attached. The two placental crests are separated by the ovarian portion of the transmitting tissue (figures 1-2). The electron micrographies 1 to 8 show the external aspect of the ovules in successive developmental stages, from the beginning of their differentiation (right side of the figure 1) to integument closure at the top of the nucellus (figure 8).

Based on the pattern of cell divisions, before the beginning of ovule ontogeny, the placental crest, as seen in a transverse section of the ovary, shows trizonate structure (figures 9, 17a). In the dermal layer (zone I) only anticlinal divisions were observed. The same pattern was observed in the subdermal layer (zone II); however, sometimes one or another cell of this layer undergoes oblique or periclinal division. In the tissue underlying the subdermal layer (zone III), there is no regular pattern of cellular divisions.

The ovule starts to differentiate with periclinal divisions in zone III (figure 17b), when the flower bud reaches about $4.5 \mathrm{~mm}$ length. The cells of the dermal and subdermal layers of the ovule primordium continue multiplying, as observed in the placenta development (figures 10, 17c). In ovaries whose carpel walls had been removed, it was observed that the primordia emerge more or less at the same time at the mid- and proximal levels of the placenta. On the other hand, there is a notable acropetal ovule development at the distal portion of the placenta (figure 1, right). There is also a certain tendency of sequential ovule development from the internal side of the placenta - close to the transmitting tissue - to the external side.

In each ovule primordium, a laterally positioned subdermal cell grows and differentiates as an archesporial cell, presenting dense cytoplasm and a prominent nucleus (figures 11, 17d). Frequently, more than one archesporial cell differentiates in the same primordium (figure 13). However, just one of them develops into a megaspore mother cell (MMC). The nucellus is quite reduced, consisting of the archesporium, the dermal cells that involve it, and some subdermal cells adjacent to the base of the archesporium. 

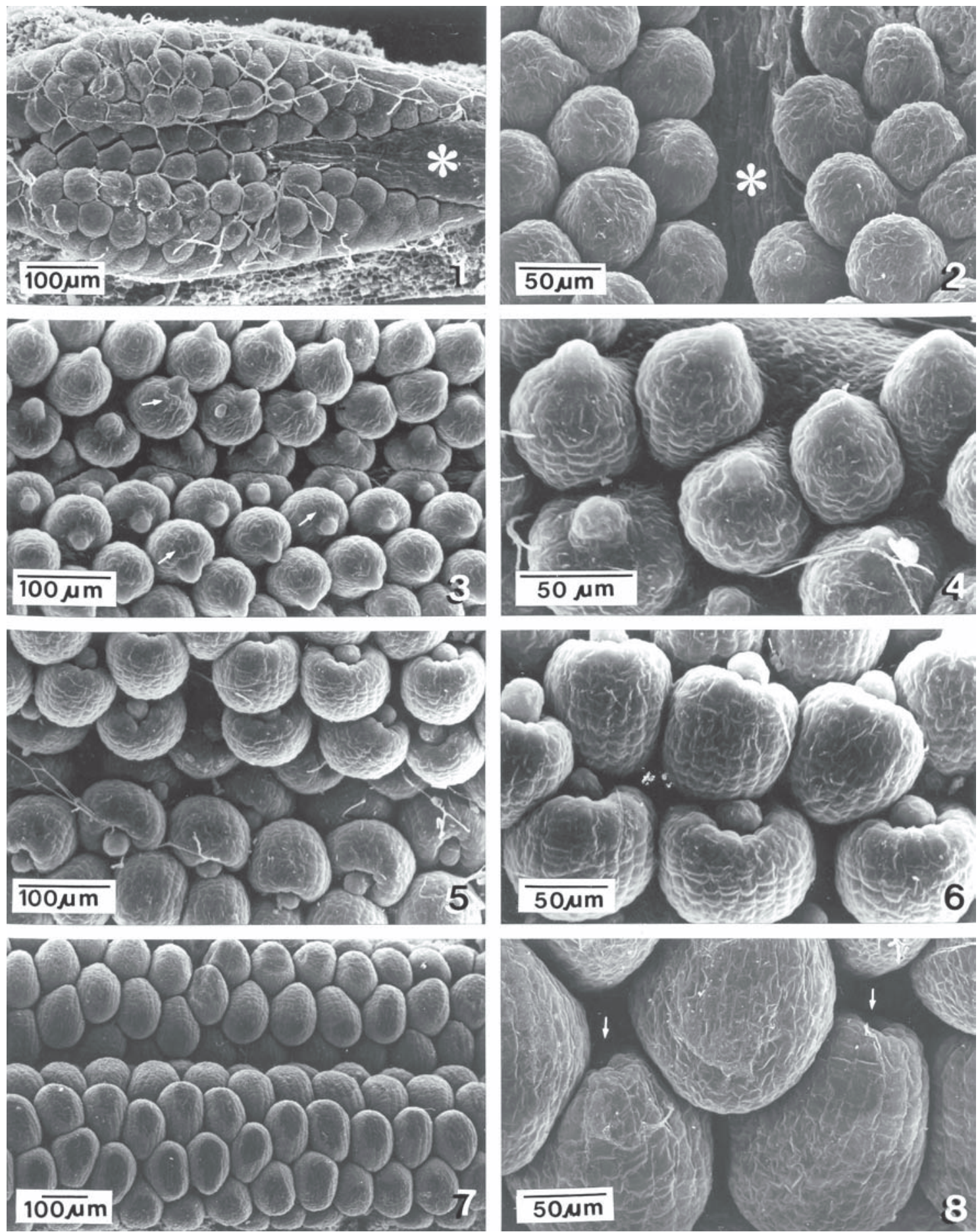

Figures 1-8. Scanning Electron-micrographs (SEM) of ovules in successive stages of development. 1. General aspect of the placentae in one of the carpels, with emergent nucelli. 2. Emergent nucelli at greater magnification. The asterisks indicate the transmitting tissue. 3. Ovules with prominent archesporium. It is possible to see the beginning of integument protrusion in several ovules (arrows). 4. The same in greater magnification. They correspond approximately to the stages shown in the figures 10-13 and 17c-f. 5. Ovules with protruding integument, corresponding to the stages shown in the figures $14 \mathrm{e} 17 \mathrm{~g}-\mathrm{h}$. 6. The same in greater magnification. 7. Ovules at the beginning of the micropyle formation. 8. The same in greater magnification. The arrows indicate the micropyle. 

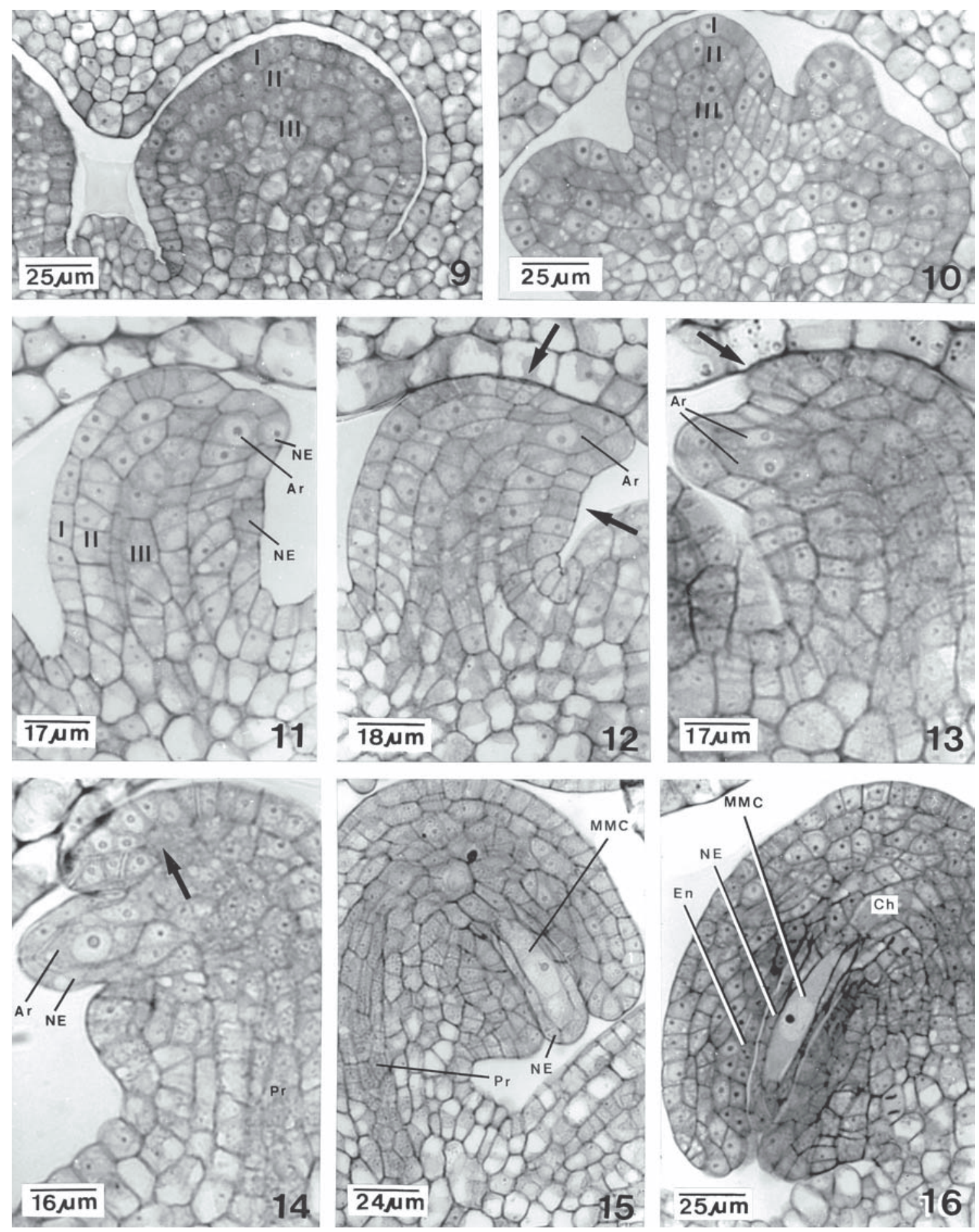

Figures 9-16. Transverse sections of the ovary showing ovules in successive stages of development. 9. Placenta with trizonate structure (before the emergence of the nucelli). 10. Placenta with the emergent nucelli. Observe the trizonate structure in one of the nucelli. 11. Nucellus with the recently differentiated archesporial cell. 12. Ovule at the beginning of integument development. Arrows indicate periclinal divisions at dermal layer. 13. Ovule with two archesporial cells. 14. Ovule in a more advanced stage, showing cells of the subdermal layer participating in the integument constitution (arrow), pushing the initials of dermal origin to the micropylar region. 15. Ovule with the recently differentiated MMC. 16. Ovule at the pre-meiotic stage. I: zone I (dermal layer); II: zone II (subdermal layer); III: zone III; Ar: archesporium; Ch: chalaza; En: endothelium; MMC: megaspore mother cell; Mi: micropyle; NE: nucellar epidermis; Pr: procambium. 

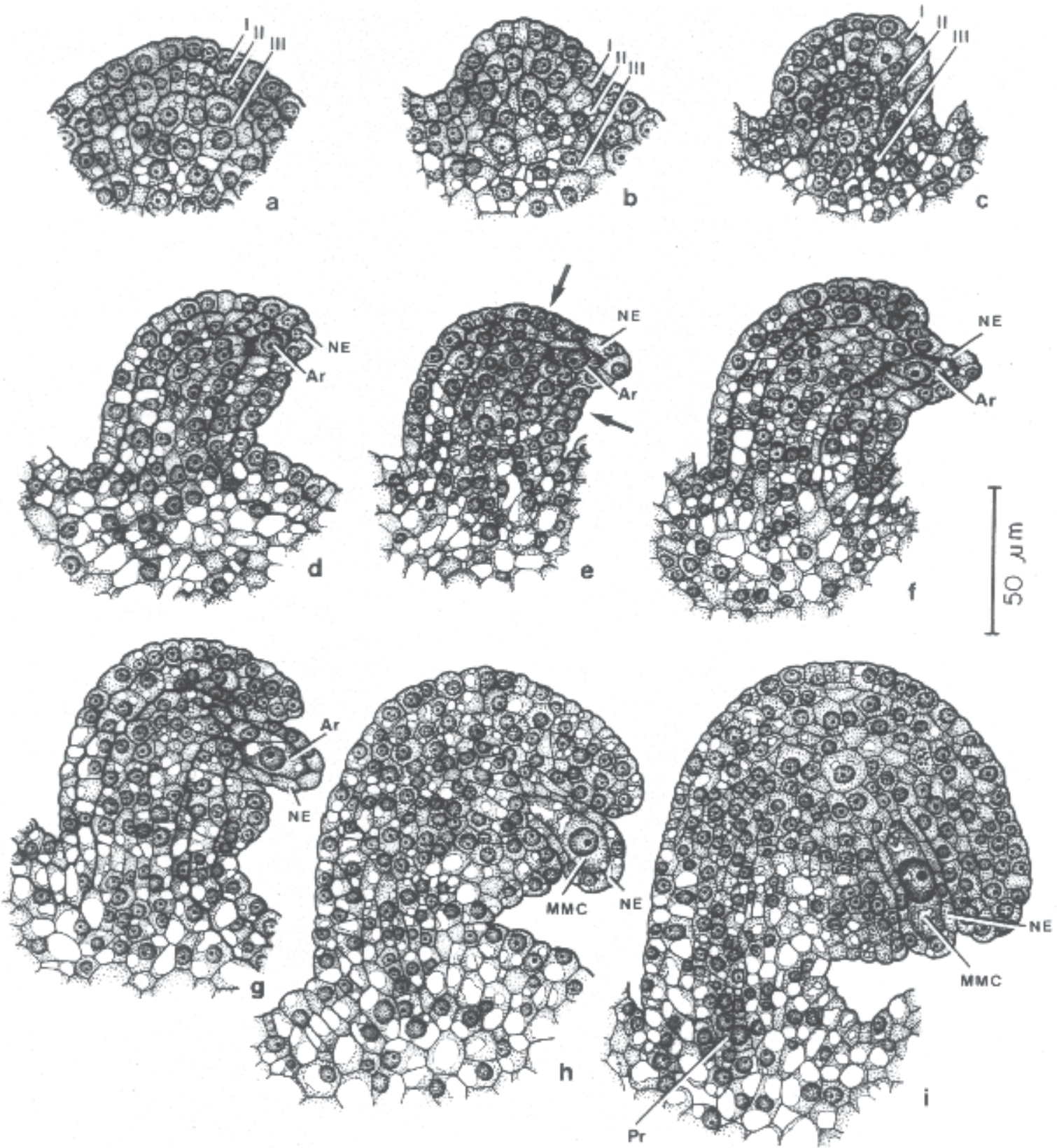

Figure 17. Ovule ontogeny - longitudinal sections of the ovule (as seen in transverse sections of the ovary) in successive stages of development. From (a) to (g) the limits among the zones I (dermal layer), II (subdermal layer), and III are represented by a thicker line. (a): Placenta. (b-c): Nucellus emergence. (d): Appearance of the archesporium. (e): The first periclinal divisions of the dermal layer (arrows) to integument formation (the same of figure 12). (f): Beginning of integument protrusion. (g): Beginning of subdermal cell participation in integument formation. (h-i) Integument growth from the base to the top of the nucellus, and MMC enlargement. Ar: archesporium; MMC: megaspore mother cell; NE: nucellar epidermis; Pr: procambium.

Quickly, each primordium starts to develop the anatropous curvature, due to differential growth of the funicular side of the ovule. At the same time, the integument is initiated by periclinal divisions in cells of the dermal layer, around the base of the archesporium (figures 12,17e - arrows). Simultaneously, or soon after, cells of the subdermal layer, just below the dermal initials, start to divide periclinally. The dermal cells continue multiplying by periclinal or oblique divisions, but they are pushed, by the subdermal cells, to the micropylar area of the integument (figures 14, 17f-g). In subsequent stages, the boundaries between the tissues of dermal and subdermal origin become obscure. At the opposite side to the funiculus, while the cells of the most external layer multiply only by anticlinal divisions, periclinal or oblique divisions in the internal layers contribute to 
increase the integument thickness. Therefore, a single and solid integument grows around the nucellus, and its cells are derived from the dermal and subdermal layers. The zone III cells of the ovule primordium do not participate in the integument constitution.

A vascular bundle (procambium) begins to differentiate in the funiculus (figures 14, 15, 17h-i). However such differentiation is not concluded before the initial stages of embryo and endosperm development. The archesporial cell starts directly to function as a MMC without giving rise to any parietal cell. This cell becomes elongated, with a quite conspicuous nucleus and its proximal wall stays in direct contact with the chalazal cells (figures 15, 16, 17h-i).

Usually at the meiotic stage, the integument margin reaches the top of the nucellus (figure 16). Both the nucellar epidermis and the inner integument surface are covered by a fine cuticle (figures 18-23). The inner parietal layers of the integument, $i$. e. closest to the nucellar epidermis, differentiate into an endothelium with tangentially elongated cells, and very dense cytoplasm (figures 24-26). The number of cell strata in the endothelium varies from one to three, according to the area, and the boundary between the endothelial and nonendothelial cells in the integument many times is not quite evident. Periclinal, oblique and anticlinal divisions in the endothelial cells were very frequently observed (figures $18,19,21,22,25,26)$. This intense mitotic activity obscures the limit between the endothelium and the outer cell layers of the integument, and is responsable for the variability of the number of endothelial cellular layers. The high metabolic activity of the endothelial cells was also indicated by the prominent nucleoli, and the presence of small nucleolar vacuoles, or more than one nucleolus in the same nucleus.

The cell walls at the proximal portion of the MMC, as well as the walls of the chalazal cells in contact with the base of the MMC, show slight thickening (figures $15,16,18,19)$. Such walls are stained intensely by astra blue, or rose-purple by toluidine blue $\mathrm{O}$. The strong staining of these walls by ruthenium red and the reaction with PAS indicate the accumulation of pectic substances. The chalazal cells are also characterized by dense cytoplasm with fibrous-granulated PAS-positive content in the vacuoles. The cell wall characteristics described above remain in the chalazal cells at the subsequent stages, but preliminary observations of ovule sections, after the beginning of the endosperm ontogeny, showed that the cell walls of the chalaza acquire a greenish tone with toluidine blue $\mathrm{O}$, indicating the presence of phenolic compounds.
The megasporocyte undergoes meiosis (figures 18-23) where the metaphasic plates are always perpendicular to the longitudinal axis of the meiocyte (figure 19) and, after successive cytokinesis, forms a linear tetrad of megaspores (figure 23). During anaphase I and II, it seems there is no synchronized migration among the chromossoms (figures 20,22). The dyad cells are of the same size (figures 21) and cellularization is followed by callose deposition on both sides of the transverse pectocellulosic wall. Usually there is no synchrony between these two cells in the subsequent meiotic stages, and the events of the second meiotic division are faster at the proximal cell (figure 22). After meiosis, the cytokinesis is accompanied once again by callose deposition on both sides of the new transverse walls. The micropylar megaspore is usually a little more elongated than the two intermediate megaspores, but the chalazal megaspore is always the largest (figure 23). Callose is also formed on the inner face of the lateral walls of the three distal cells, as well as on the inner face of the distal wall of the micropylar megaspore, although to a lesser degree. On the inner face of the chalazal megaspore lateral walls, callose deposition occurs only in the distal portion of the cell. Only the chalazal megaspore is functional, gradually increasing in volume, while the micropylar megaspores degenerate (figure 27).

After they reach the top of the nucellus, integument margins are projected beyond that point, originating the micropyle (figures 27,28). The integument cells around the micropylar channel also become endothelial cells. During meiosis, amyloplast development begins in the endothelium, especially in the micropylar portion. In subsequent stages, other cells of the integument and funiculus, close to the endothelium, also differentiate amyloplasts, but in the endothelial cells they are always larger and more numerous (figures 28, 29).

The chalazal megaspore expands considerably, becoming elongated and with a quite conspicuous central nucleus (figures 28, 29). The callose persists as a hood involving the micropylar portion of the chalazal megaspore, although thinning progressively as development continue. Small spherical vacuoles grow at the two poles of the megaspore, during its expansion (figure 27). Such vacuoles fuse to one another and, at the end of the uninuclear stage, the embryo sac mother cell presents wide bipolar vacuolation (figures 28, 29). Accumulation of a fibrous-granulated PAS-positive material, similar to that verified in the chalazal cells, was also observed inside the embryo sac mother cell vacuoles (figure 29). Cells of the nucellar epidermis begin to 

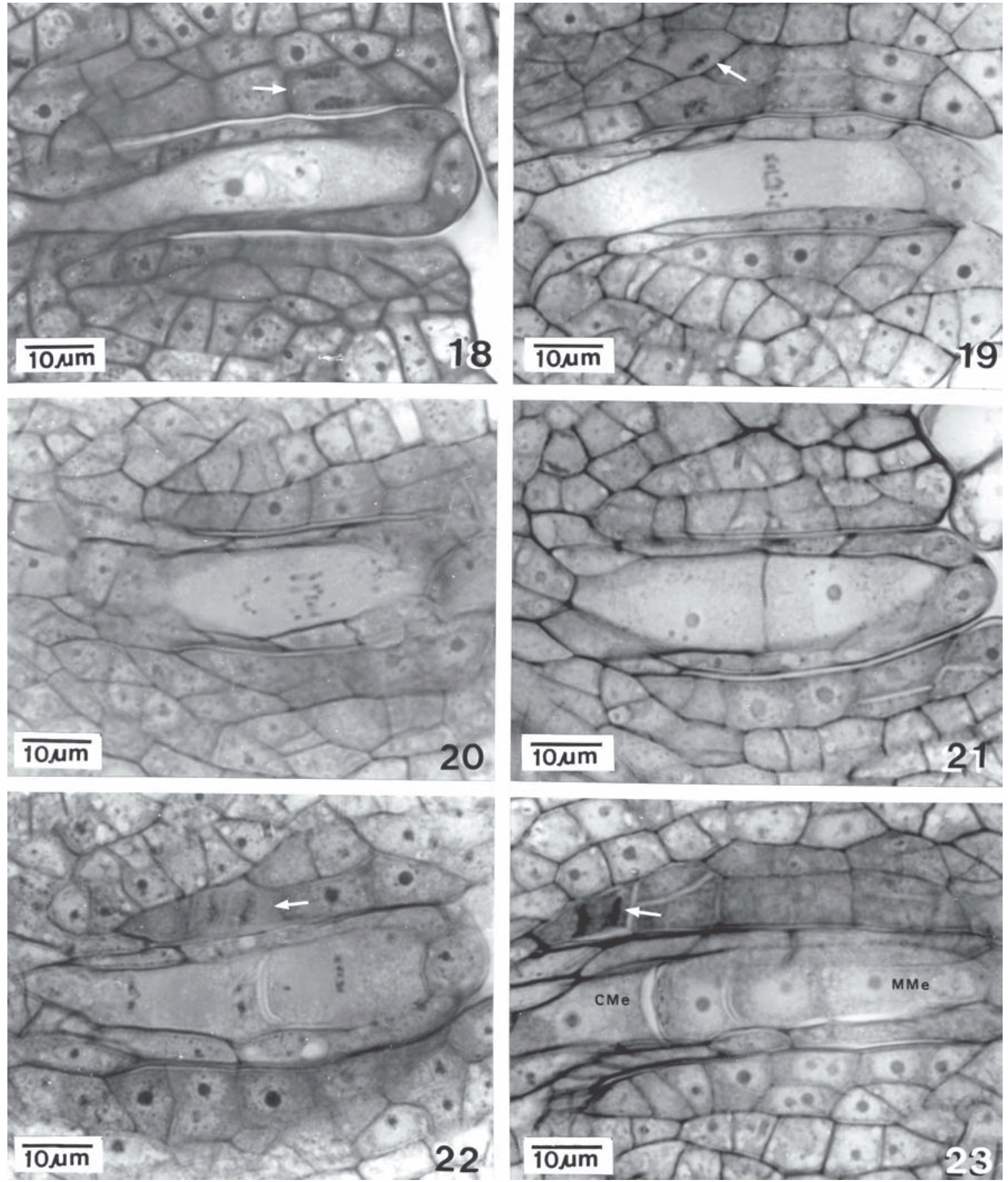

Figures 18-23. Longitudinal sections of meiocytes in sucessive stages of the meiosis. 18. Prophase I. 19. Metaphase I. 20. Anaphase I. Observe the uncoordinated migration of the chromosomes. 21. Dyad stage (prophase II). 22. Metaphase/anaphase II. At the chalazal dyad cell (left), two separated groups of chromosomes are shown (end of anaphase II), while in the micropylar cell (right) almost all chromosomes are still organized in a metaphase plate. 23. Megaspore tetrad just after the second meiotic cytokinesis. CMe: chalazal megaspore; MMe: micropylar megaspore. The arrows indicate endothelial cells in mitotic divisions. 

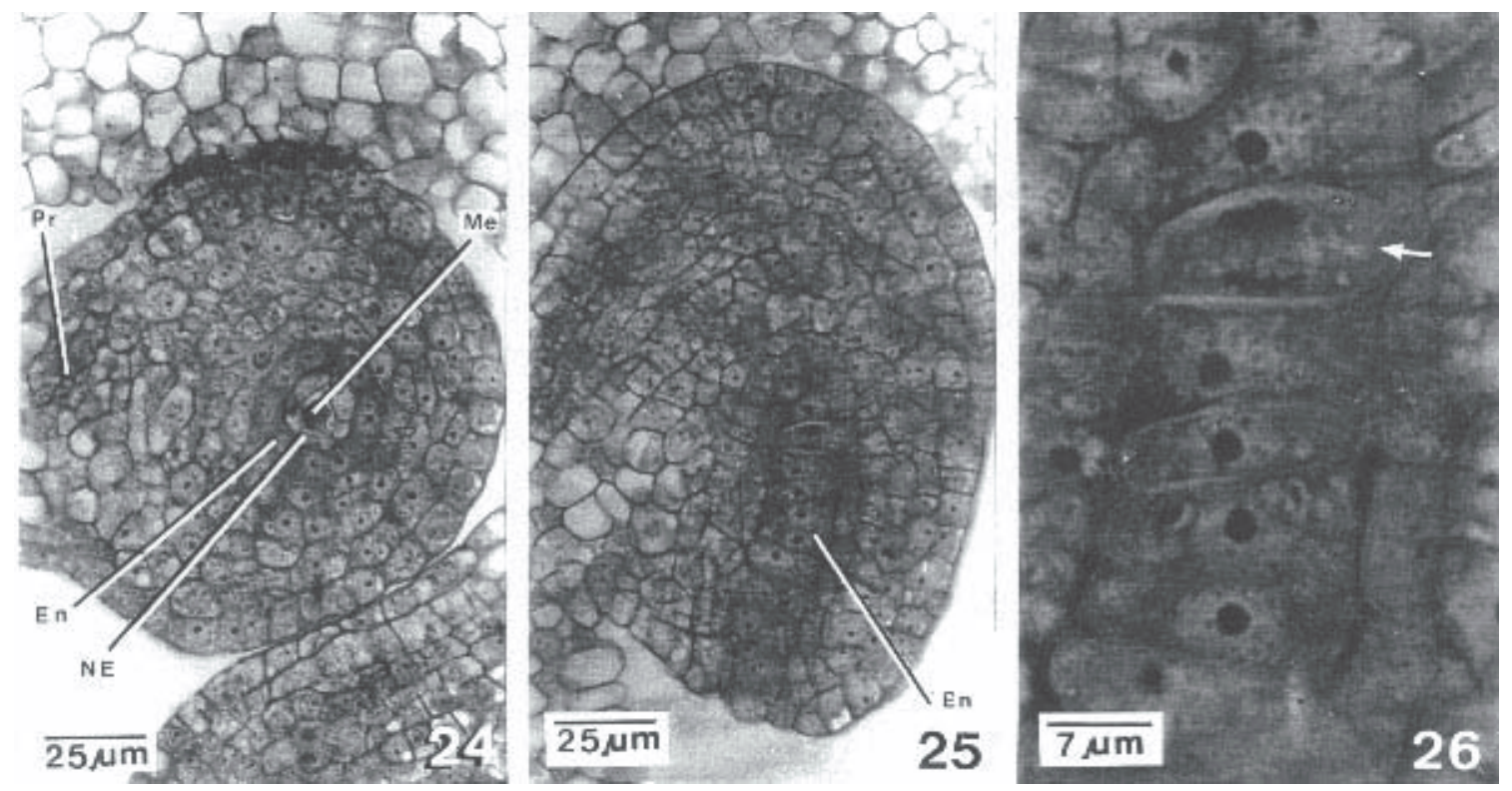

Figures 24-26. Endothelium as seen in different section types. All at the tetrad stage 24. Transverse section of the ovule. 25. Tangential longitudinal section of the ovule showing the tangentially elongated endothelial cells. 26. The endothelial cells (the same of figure 25) in greater magnification. The arrow indicates a cell in mitotic division. En: endothelium; Me: megaspore; NE: nucellar epidermis; Pr: procambium.
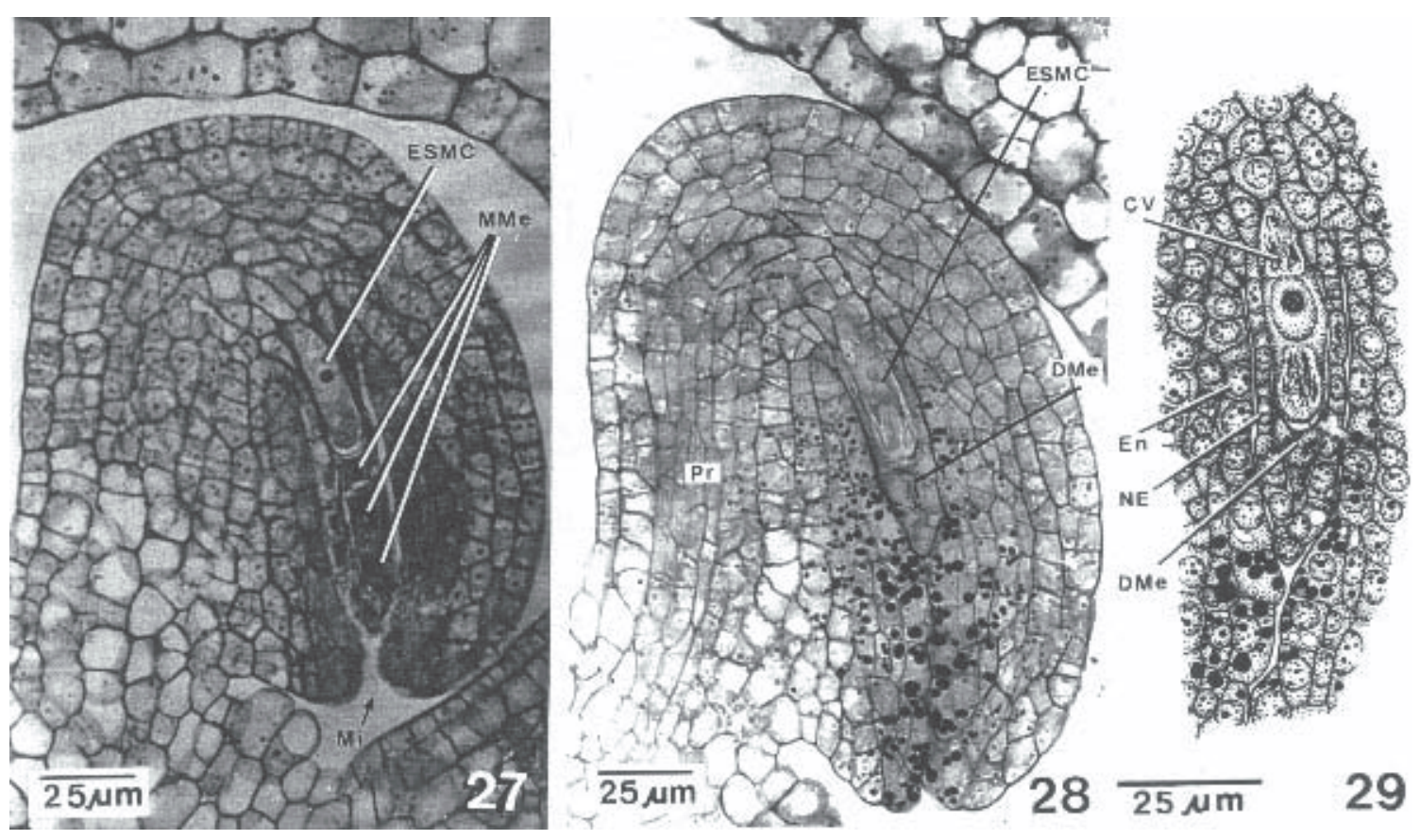

Figures 27-29. Longitudinal sections of the ovule in two successive stages after meiosis. 27. Tetrad stage with the developing chalazal megaspore (ESMC) and the degenerating micropylar megaspores. 28. Mature ESMC stage. The section was submitted to the PAS reaction, and the dark rounded corpuscles are amyloplasts. 29. The mature ESMC (the same of figure 28) in greater magnification. CV: chalazal vacuole of the mature ESMC; DMe: degenerated megaspores; En: endothelium; ESMC: embryo sac mother cell; Mi: micropyle; MMe: micropylar megaspore; NE: nucellar epidermis; Pr: procambium. 
present the first signs of nuclear pycnosis, indicating the beginning of their degeneration.

\section{Discussion}

Histologically, the young placentae and the ovule primordia present a tunica-corpus organization. The tunica is constituted of two layers: the dermal layer (zone I), in which only anticlinal divisions occur, and the subdermal layer (zone II), where anticlinal divisions are predominant. The corpus corresponds to the central area (zone III), where there is no regular pattern of cellular divisions. The trizonate character of the ovule primordia is common to several angiosperm families (Bouman 1984). Periclinal divisions in zone III of the placenta initiate the ovule in T. pulcherrima. Satina (1945) demonstrated the same process in Datura stramonium using cytochimeric induction. Other authors have also indicated zone III as the site of ovule initiation in several taxa (Bhandari et al. 1976, Bouman \& Calis 1977, Bouman \& Schier 1979, Bouman 1984, Venturelli \& Bomtempi Jr. 1989). In spite of the clear trizonate structure observed in the ovule primordium of T. pulcherrima, Galati \& Strittmatter (1999) interpreted the ovule primordium organization in Jacaranda mimosifolia as bizonate, initiated by periclinal divisions in the second cell layer of the placenta.

Although, occasionally, more than one archesporial cell can differentiate in the ovule primordium of $T$. pulcherrima, only one of them reaches the MMC stage. The differentiation of more than one archesporial cell in the same ovule has also been described in other Bignoniaceae, such as Bignonia megapotamica (Swamy 1941), Kigelia pinnata, Tecoma stans (Govindu 1950) and Tabebuia ochracea (Bittencourt Jr. 1992). In the first three species mentioned, more than one archesporial cell can grow to reach more advanced stages, occasionally originating two tetrads in the same nucellus. As stated by Bouman (1984), many taxa present a multicellular archesporium, and it is responsible for some cases of polyembryony or apomixis. The direct differentiation of archesporial cell in a MMC observed in T. pulcherrima - i. e., without originating any parietal cell - has also been reported in all the Bignoniaceae investigated up to now (Duggar 1899, Mauritzon 1935, Swamy 1941, Govindu 1950, Ghatak 1956, Mehra \& Kulkarni 1985, Bittencourt Jr. 1992, Galati \& Strittmatter 1999).

Integument ontogeny in unitegmic ovules is of great interest in the taxonomic study of the sympetalous plants. Warming (1878) concluded that the integument in sympetalous taxa is derived mainly from the dermal layer. In Datura stramonium (Satina 1945) and Scrophularia himalensis (Bhandari et al. 1976) a dermal origin of the integument was also reported. However, Bouman \& Schier (1979) pointed out that, in unitegmic/sympetalous plants, the integument does not have always a exclusively dermal origin, but it can also be derived total or partially from the subdermal layer. The ovule of T. pulcherrima is unitegmic and tenuinucellate. Both dermal and subdermal layers are involved in the formation of the integument. Venturelli \& Bomtempi Jr. (1989) observed the same position shifting of the dermal initials to the micropylar area in the integument development of Antonia ovata. In Gentiana cruciata and $G$. asclepiadea (Bouman \& Schier 1979), integument ontogeny is very similar to that observed in $T$. pulcherrima, except for the beginning of the periclinal divisions of the subdermal layer, which only happens after the dermal cells have reached the top of the nucellus. The dermal cells close to micropylar extremity of the integument have often been interpreted as homologous to the internal integument of the bitegmic ovule (Bouman \& Calis 1977, Bouman \& Schier 1979, Bouman 1984). According to these authors, the change of position of the dermal cells to the micropylar region is inherent to one of the three phylogenetic roads that led to the unitegmy. A different pattern of integument initiation seems to occur in Jacaranda mimosifolia, since a dermal origin was reported in this species (Galati \& Strittmatter 1999).

As it is usual in anatropous ovules, the funicular or basiovular side of the integument presents a much less expressive development than on the opposite side. In the latter, periclinal or oblique divisions of the inner cellular layers contribute to increase the thickness of the integument, but in the outermost layer, only anticlinal divisions take place. Bouman (1971) observed the same pattern of cellular divisions in the solid external integument of the bitegmic ovule of Lilium.

In the Bignoniaceae, an endothelium was also observed in Tecoma stans, Parmentiera cereifera, Jacaranda mimosifolia, Kigelia pinnata (Govindu 1950), Oroxilum indicum (Ghatak 1956), Tabebuia rosea, Milingtonia hortensis, Dolichandrone falcata, Heterophragma adenophyllum, Stereospermum chelonoides (Mehra \& Kulkarni 1985), and Jacaranda mimosifolia (Galati \& Strittmatter 1999). In Tabebuia ochracea (Bittencourt Jr. 1992) the endothelium is similar to that observed in T. pulcherrima. According to Kapil \& Tiwari (1978a) an endothelium is commonly found in the sympetalous angiosperms with unitegmic 
and tenuinucelate ovules. These authors pointed out that the endothelium could carry out several functions in different developmental stages. In the initial stages the endothelium commonly exhibits meristematic cell ultrastructure. Once they divide profusely during the first ontogenetic stages of the megagametophyte and of the endosperm, the endothelial cells enable coordinated development between the embryo sac/young endosperm and the integument. In other stages, the endothelium channels nutritious substances to the embryo sac and to the endosperm. In several species, particularly in Scrophulariaceae, the endothelium starts to exercise a protective function of the embryo, during seed development (Kapil \& Tiwari 1978a).

In the species studied by Govindu (1950) the endothelium differentiates only after the disorganization of the nucellar epidermis. In the species analyzed by Mehra \& Kulkarni (1985), endothelium differentiation occured simultaneously with nucellar epidermal disruption, coinciding with the binuclear stage of the embryo sac. Nevertheless the exact moment in which the endothelium begins to differentiate is very variable (Kapil \& Tiwari 1978a). Both in Tabebuia ochracea and T. pulcherrima the endothelium is observed even before the MMC undergoes meiosis, when the nucellar epidermis is still intact.

Mehra \& Kulkarni (1985) observed that, during endosperm development, the endothelial cells which surround the chalazal haustorium are organized in a palisade, and they contain dense cytoplasm. Govindu (1950) mentions that endothelial cells which establish direct contact with the developing embryo sac become radially elongated, and reach maximum development after megagametophyte cellularization. In Tabebuia pulcherrima the endothelial cells are tangentially elongated, and accumulate large quantities of starch grains, especially in the cells surrounding the micropylar channel. Similar deposition of amyloplasts into the cells of the micropylar channel was found in Jacaranda mimosifolia (Galati \& Strittmatter 1999) and other angiosperms (Tilton 1980a). Amyloplast accumulation in the micropylar channel cells seems to be associated to their function in the nourishment of the developing megagametophyte (Tilton 1980a, Bittencourt Jr. 1992, Bittencourt Jr. \& Mariath 2002), or more probably are closely involved in embryo nutrition (Tilton 1980a). However, a different interpretation was suggested by Galati \& Strittmatter (1999) and other authors (Tilton 1981a), according to whom amyloplast accumulation in the cells that surround the micropylar channel may be related to growth of the pollen tube.
The chalazal cells in Tabebuia pulcherrima characteristically present slightly thickened, pectin-rich walls, which acquire a greenish color - with toluidine blue $\mathrm{O}$ - after fertilization, probably due to lignin deposition. The chalazal tissue therefore differentiates into a hypostase, like that described by Tilton (1980b) for Liliaceae. Bittencourt Jr. (1992) observed the same chalazal cells with dense content and thick walls, but he did not detect any sign of lignification in $T$. ochracea. Hypostase formation is a characteristic feature of the ovule in several Bignoniaceae (Mauritzon 1935, Swamy 1941, Govindu 1950, Ghatak 1956, Mehra \& Kulkarni 1985, Johri et al. 1992, Galati \& Strittmatter 1999). According to Mehra \& Kulkarni (1985), the hypostase stops the growth of the aggressive chalazal endosperm haustorium, during seed development. Because the chalazal cells are located between the distal end of the funicular vascular bundle and the base of the embryo sac, and due their dense cytoplasm, Swamy (1941) and Govindu (1950) suggested that the chalazal cells would have a function on the active translocation of nutrients to the developing megagametophyte. According to Tilton (1980b), the chalazal cells should be interpreted as constituting a hypostase, even when their cell walls are not lignified. The same author pointed out that the function of the hypostase is not known with certainty but because of its position around the chalazal end of the megagametophyte, it is generally thought to be related to the translocation of nutrients into the megagametophyte and embryo. Furthermore, it is possible that, at the ultrastructural level, both the walls of the chalazal cells and the proximal portion of the MMC/embryo sac wall in Tabebuia pulcherrima actually function as transfer cell walls, which needs to be confirmed.

The accumulation of a fibrous-granulated content was observed in the chalazal cell vacuoles and in the embryo sac mother cell bipolar vacuome of T. pulcherrima. The PAS reaction suggests the polysaccharide nature of this substance. It is probably translocated from the chalazal cells to the vacuome of the expanding embryo sac mother cell. Similarly, the contents of some chalazal cells in immature Ornithogalum caudatum ovules stain intensely for what appears to be carbohydrate different from starch, and was associated to the nutritive function of the hypostase (Tilton 1980b). In soybean, Folsom $\&$ Cass (1989) observed the coalescence of vesicles, originated in the dictyosomes, within the vacuome of the expanding embryo sac. The authors interpreted the phenomenon as the addition of osmotically active substances to the vacuoles, which may be responsible 
for the maintenance of the necessary osmotic pressure for embryo sac expansion. We may speculate if a similar function could be exercised by the fibrous-granulated content observed in the embryo sac mother cell vacuome of $T$. pulcherrima.

The meiotic division of the megasporocyte always results in a linear tetrad of megaspores, which only the chalazal megaspore grows to give rise to the megagametophyte. From all the Bignoniaceae until now investigated, occasional variations of this pattern were only observed in Kigelia pinnata, whose tetrad can be T-shaped or in an isobilateral arrangement, and in Parmentiera cereifera, whose tetrad can be organized in a decussate arrangement (Govindu 1950).

Callose formation during the megasporogenesis is a phenomenon of wide occurrence in the angiosperms, and may act as a barrier for some nutrients, possibly leading to starvation and abortion of the non-functional megaspores (Rodkiewicz 1970, Kapil \& Tiwari 1978b, Kapil \& Bhatnagar 1981, Willemse 1981, Huang \& Russell 1992, Colombo \& Angenent 1999). It is known that the callose distribution in the cell walls undergoes changes according to the stage of the megasporogenesis and varies according to the type of embryo sac development. In the Polygonum type, the callose has been reported to appear first in the chalazal region of the megasporocyte during prophase I. Subsequently, the callose is deposited around the whole meiocyte. In the transverse walls of the dyads, triads and tetrads, callose is also deposited, but it disappears from the proximal region of the chalazal megaspore wall (Rodkiewicz 1970). However, in Tabebuia pulcherrima the callose appears successively in the transverse walls of the dyads, tetrads, and only then appears in the lateral walls, as well as in the distal wall of the micropylar megaspore. No callose deposition was observed in the MMC wall or at the chalazal region of the embryo sac mother cell. Similarly, in Jacaranda mimosifolia, Galati \& Strittmatter (1999) did not observed any callose deposition in the MMC wall. The callose hood formed on the micropylar pole of the embryo sac mother cell of T. pulcherrima gradually disappears during the last half of its expantion, at the same time in which the nonfunctional megaspores are absorbed. These results are in disagreement with the postulates of Rodkiewicz (1970), according to which the callose deposition in the MMC wall takes place firstly on the pole where the functional megaspore will be formed, and that the subsequent callose deposition around the whole meiocyte temporarily isolates it from the somatic tissues.

On the other hand, the present observations strongly indicated that the chalazal megaspore is favored from the beginning, not only by its position - more nutritionally advantageous due the proximity with the chalaza - but also by the distribution of the callose in the tetrad. The condition in which the chalazal megaspore becomes functional is the commonest among the angiosperms (Kapil \& Bhatnagar 1981, Willemse 1981, Huang \& Russell 1992). It seems quite possible that the cellularization and the simultaneous callose deposition on the transverse pectocellulosic walls of the dyad and tetrad in T. pulcherrima promptly block free metabolite diffusion among the megaspores. Finally, after the callose deposition on the other walls of the three micropylar megaspores, the flow of metabolites coming from somatic tissues to the micropylar megaspores is restricted, which may contribute to their degeneration. Therefore the selection of the functional megaspore in T. pulcherrima is related to the pathway of nutrition supply, an idea that is supported by several studies in other angiosperms (Rodkiewicz 1970, Kapil \& Tiwari 1978b, Kapil \& Bhatnagar 1981, Willemse 1981, Huang \& Russell 1992, Colombo \& Angenent 1999).

No sign of asymmetry was observed in the premeiotic MMC. However, there is a short delay of the second meiotic division in the dyad micropylar cell, which can be interpreted as a sign of polarity between the two cells, possibly related to the callose deposition in the transverse wall between them. It is interesting to point out that Sniezko \& Harte (1984) also observed a delay of the meiosis II on the chalazal side in Oenothera, a group in which the micropylar megaspore is usually selected as functional. In T. pulcherrima, the second division in the chalazal cell, and not rarely also in the micropylar cell, is sharply unequal. At the tetrad stage, the largest volume of the distal micropylar megaspore relatively to the two intermediate ones probably is associated to its largest contact surface with the nucellar epidermis, since callose deposition in the micropylar wall of this cell is simultaneous to its deposition in the lateral walls. The illustrations furnished by Swamy (1941) suggest that the same may happen in Bignonia megapotamica. However, this author observed cases in which the micropylar megaspore was as large as the chalazal one, interpreting such tetrads as anomalous.

In conclusion, ovule primordia in Tabebuia pulcherrima have a trizonate structure, in which a single integument is originated from the dermal and subdermal layers. These features may be important at generic level of Bignoniaceae taxonomy because a different condition - i. e., bizonate with a dermal origin of the integument was reported in Jacaranda (Galati \& Strittmatter 1999). 
The endothelial cells show intense mitotic activity and accumulate large quantities of starch. In more advanced stages, part of this endothelium become disorganized, and are probably absorbed by the developing embyo sac (Bittencourt Jr. \& Mariath 2002). These features suggest at least two endothelial functions: nourishment of the developing embryo sac, and developmental coordination between the megagametophyte /endosperm and integument growth. The supposed taxonomic significance of the presence or absence of the endothelium in some species, as well as the moment of endothelium initiation in Bignoniaceae need additional investigation. The patterns of cell divisions and callose deposition in the Polygonum type megasporogenesis of T. pulcherrima suggest a genetically programmed sequence of events, in which the selection of the functional megaspore is strongly correlated with the location of callose deposit and the establishment of a specific pathway of nutrition supply.

Acknowledgements - We would like to thank Coordenação de Aperfeiçoamento de Pessoal de Nível Superior (CAPES), for grant support to the first author, and Conselho Nacional de Desenvolvimento Científico e Tecnológico (CNPq), for the research grant to the second. We also thanked the two anonymous reviewers for the critical reading and valuable suggestions for the manuscript, and Dr George Shepherd for english improvement.

\section{References}

BHANDARI, N.N., BOUMAN, F. \& NATESH, S. 1976. Ovule ontogeny and seed coat structure of Scrophularia himalensis Royle. Botanisch Jahrbuecher fuer Systematik Pflanzengéschichte und Pflanzengeographie 95:535-548.

BITTENCOURT JR., N.S. 1992. Anatomia floral de Tabebuia ochracea (Cham.) Standley (Bignoniaceae): histologia, vascularização e ontogenia com especial referência ao desenvolvimento do óvulo e da antera. Monografia de Graduação, Universidade Federal de Minas Gerais, Belo Horizonte.

BITTENCOURT JR., N.S. \& MARIATH, J.E.A. 2002. Ovule ontogeny of Tabebuia pulcherrima Sandwith (Bignoniaceae): the development of the embryo sac. Revista Brasileira de Botânica (in press).

BOUMAN, F. 1971. The application of the tegumentary studies to taxonomic and phylogenetic problems. Berichte der Deutshen Botanischen Gessellschaft 84:169-177.

BOUMAN, F. 1984. The ovule. In Embryology of angiosperms (B.M. Johri, ed.). Springer-Verlag, Berlin, p.123-157.

BOUMAN, F. \& CALIS, J.J.M. 1977. The integumentary shifting. A third way to unitegmy. Berichte der Deutscen Botanischen Gessellschaft 90:15-28.
BOUMAN, F. \& SCHIER, S. 1979. Ovule ontogeny and seed coat development in Gentiana, with a discussion on the evolutionary origin of the single integument. Acta Botanica Neerlandica 28:467-478.

COLOMBO, L. \& ANGENENT, G.C. 1999. MADS box genes controlling ovule and seed development in Petunia. In Fertilization in higher plants. Molecular and cytological aspects (M. Cresti, G. Cai \& A. Moscatelli, eds.). SpringerVerlag, Berlin Heidelberg, p.351-360.

DUGGAR, B.M. 1899. On the development of the pollen grain and embryo-sac in Bignonia venusta. Bulletin of the Torrey Botanical Club 26:89-105.

ESCHRICH, W. \& CURRIER, H.B. 1964. Identification of callose by its dichrome and fluorochrome reactions. Stain Technology 39:303-307.

FOLSOM, M.W. \& CASS, D.D. 1989. Embryo sac development in soybean: ultrastructure of megasporogenesis and early megagametogenesis. Canadian Journal of Botany 67:2841-2849.

GABRIEL, B.L. 1982. Biological electron microscopy. Van Nostrand Reinhold, New York.

GALATI, B.G. \& STRITTMATTER, L.I. 1999. Ovule ontogeny and megasporogenesis in Jacaranda mimosifolia D. Don. (Bignoniaceae). Phytomorphology 49:67-74.

GERLACH, D. 1977. Botanische Mikrotechnik - Eine Enführung. Georg Thieme Verlag, Stuttgart.

GERSTERBERGER， P. \& LEINS, P. 1978. Rasterlektronenmikroskopische Untersuchung na Blütenospen von Physalis philadelphica (Solanaceae). Berichte der Deutsche Botanischen Gesesellschaft 91:381-387.

GHATAK, J. 1956. A contribution to the life history of Oroxylum indicum Vent. Proceedings of the Indian Academy of Science B 43:17-87.

GOVINDU, H.C. 1950. Studies in the embryology of some members of Bignoniaceae. Proceedings of Indian Academy of Science B 32:164-178.

HUANG, B. \& RUSSEL, S.D. 1992. Female germ unit: organization, isolation, and function. International Review of Cytology 140:233-293.

JOHANSEN, D.A. 1940. Plant microtechnique. McGraw-Hill Book Co., New York.

JOHRI, B.M., AMBEGAOKAR, K.B. \& SRIVASTAVA, P.S. 1992. Comparative embryology of Angiosperms. Springer-Verlag, Berlin. v. 2.

KAPIL, R.N. \& BHATNAGAR, A.K. 1981. Ultrastructure and biology of female gametophyte in flowering plants. International Review of Cytology 70:291-341.

KAPIL, R.N. \& TIWARI, S.C. 1978a. The integumentary tapetum. The Botanical Review 44:457-490.

KAPIL, R.N. \& TIWARI, S.C. 1978b. Plant embryological investigations and fluorescence microscopy: An assessment of integration. International Journal of Cytology 53:291-331.

MAURITZON, J. 1935. Etwas über die Embryologie der Bignoniaceen. Botaniska Notiser (1935): 60-77. 
MEHRA, K.R. \& KULKARNI, A.R. 1985. Embryological studies in Bignoniaceae. Phytomorphology 35:239-251.

O'BRIEN, T.P. \& McCULLY, M.E. 1981. The study of plant structure principles and selected methods. Termarcarphi Pty, Melbourne.

ROBARDS, A.W. 1985. Botanical microscopy. Oxford University Press, Oxford.

RODKIEWICZ, B. 1970. Callose in cell walls during megasporogenesis in angiosperms. Planta 93:39-47.

SASS, J.E. 1940. Elements of botanical microtechnique. McGraw-Hill Book Co., New York.

SATINA, S. 1945. Periclinal chimeras in Datura in relation to the development and structure of the ovule. American Journal of Botany 32:72-81.

SHIVARAMIAH, G. 1998. Endosperm development in Bignoniaceae. Phytomorphology 48:45-50.

SNIEZKO, R. \& HARTE, C. 1984. Polarity and competition between megaspores in the ovule of Oenothera hybrids. Plant Systematics and Evolution 144:83-97.

SOUTHWORTH, D. 1973. Cytochemical reactivity of pollen walls. The Journal of Histochemistry and Cytochemistry 21:73-80.
SPANGLER, R.E. \& OLMSTEAD, R.G. 1999. Phylogenetic analysis of Bignoniaceae based on the cpDNA gene sequences $r b c \mathrm{~L}$ and $n d h \mathrm{~F}$. Annals of the Missouri Botanical Garden 86:33-46.

SWAMY, B.G.L. 1941. Contributions to the life history of Bignonia megapotamica. Journal of the Indian Botanical Society 20:299-305.

TILTON, V.R. 1980a. The nucellar epidermis and micropyle of Ornithogalum caudatum (Liliaceae) with a review of these structures in other taxa. Canadian Journal of Botany 58:1872-1884.

TILTON, V.R. 1980b. Hypostase development in Ornithogalum caudatum (Liliaceae) and notes on other types of modifications in the chalaza of angiosperm ovules. Canadian Journal of Botany 58:2059-2066.

VENTURELLI, M. \& BOMTEMPIJR., N. 1989. Ovule ontogeny and seed coat development in Antonia ovata Pohl. (Loganiaceae). Revista Brasileira de Botânica 12:11-16.

WARMING, E. 1878. De l'ovule. Annales des Sciences Naturales A. Botanique 5:177-266.

WILLEMSE, M.T.M. 1981. Polarity during megasporogenesis and megagametogenesis. Phytomorphology 31:124-134. 